\title{
Potential Development of Tourism Village in Hendrosari Village, Menganti District, Gresik City
}

\author{
Author \\ Heri Cahyo Bagus Setiawan (Orcid ID. 0000-0001-9983-8951), \\ Aries Kurniawan (Orcid ID. 0000-0003-1788-7974), \\ Muhammad Ghufran Ramdhani (Orcid ID. 0000-0002-9983-8951), \\ Ragillia (Orcid ID. 0000-0003-9983-8951). \\ Correspondence \\ Universitas Muhammadiyah Gresik. \\ hericbs@umg.ac.id, ariesaja@umg.ac.id, danirambo89@gmail.com, \\ putriragil1992@gmail.com
}

\begin{abstract}
:
The PKM program that is a partner is Hendrosari Village, Menganti District, Gresik City. Villages that have the potential to be developed into tourist villages. The vast land and other economic potentials seem to have been built by this village. However, this potential is not yet optimal in practice. Because through this PKM program we focus on renewing, and some training related to maximizing the potential of villages that become tourist villages.

In this PKM program we try to provide alternatives and solutions that provide modern and agro-based business support by providing seminars and workshops related to agro-based business management, change management (change from traditional culture to modern culture in the management of business management. It is expected that the existing potential can be optimized in increasing the economic efforts of the community through agro-tourism based KUEMDes and the use of technology that produces potential resources that can become a source of income for rural communities.

This activity was created successfully in the form of creating successful collaborative programs until the end of the PKM, building a family atmosphere between the different and solving problems related to shared problems so that they can be used together to find solutions and find out how to increase the economic benefits of this village if used moderately based on agro-industry and siwalan agro-tourism, of course the hope is to achieve the expected benefits, namely increased knowledge, increased productivity and competitiveness, independence and welfare of the community through the utilization of the potential of villages as lontar tourism villages.
\end{abstract}

Keywords: Development, village potential, tourism village

Received: 22 June 2020. Accepted: 07 August 2020

\section{Introduction}

Hendrosari village is located in the Menganti District area of Gresik Regency with a position limited by the territory of neighboring villages. In the north it is bordered by Pandu Village in Cerme Subdistrict, in the West it is bordered by Cerme Village in Cerme Subdistrict In the South it is bordered by Boboh Village in Menganti District, while in the east it is bordered by Kepatihan Village in Menganti District. The distance from Hendrosari Village to the subdistrict capital is $4 \mathrm{~km}$, which can be reached in about 0.20 hours while the distance to the regency capital is $14 \mathrm{~km}$, which can be taken in about 0.75 hours.

The area of Hendrosari Village is 192 hectares, which is administratively divided into 2 hamlets namely Hendrosalam and Hendrosari. The division of land in the village of Hendrosari is predominantly on the Siwalan Tree Farm and Rice crops in the rainy season while Corn and Polowijo in the dry season.

This village is famous for its main crops rarely found in other regions, namely Trees Siwalan This tree produces two natural products, the first is Legen and the second is Siwalan Fruit. Original Legen produced by siwalan tree in Hendrosari Village has an extraordinary function for health because it can treat various diseases, including: Kidney stones, Urinary tract pain, Back / waist pain due to being too tired / irregular in consuming rinking water.

BUMDesa or KUMDes Hendrosari was established in 2016 with Village Capital 
Participation from the Village Fund of Rp. 30,000,000, - With the Online Savings and Loans \& Payment Unit. And for 2017 there is an additional capital of Rp. 30,000 .000.

At present, waste management and business activity development in the service

The development of another line of business carried out is the Lontar Sewu Tourism Village. This field is realized in the collaboration of Hendrosari Village with the Ministry of Village through the 2019 Local Economic Development Village Incubation Pilot Program.

The funds disbursed by the Ministry of Villages, Disadvantaged Regions and Transmigration reached Rp.1.3 billion. This fund was added with assistance funds from the APBDes of Rp.300 million.

This program certainly opens opportunities for increased economic and entrepreneurial activity in the village. Automatically, village land can develop the potential as a source of income to increase village income.

During this time the economic and entrepreneurial movement of Lontar Sewu Village in the field of selling legens and culinary preparations made from chicken. For income legen taker can reach Rp.5 million to Rp. 10 million per month. With an average sales of legens which reach Rp.200 thousand to Rp.300 thousand per day. With a selling price of Rp.10 thousand to Rp.20 thousand per liter.

Opportunities for people who earn income in this field are only for farmers who have siwalan plants. In fact, siwalan plants are not easy to develop like other types of plants. Because, these plants usually naturally grow by themselves.

The second is in the culinary field. Processed chicken dishes in the village of Hendrosari are already famous. Grilled chicken with a selling price of Rp.125 thousand per head is a superior product.

However, these have not been able to provide an optimal impact on village income. In fact, some of the Village Owned Enterprises that have been running are still experiencing sector. With a population of 3,165 people, it is potential to develop other business activities, especially in the service sector. Among them are payment services for water and electricity bills. Fields can be carried out besides the savings and loan field.

problems to be able to have an optimal impact on village development and village income contribution.

Community waste management, for example, until now has not been able to contribute to community income.

Likewise for other superior products such as siwalan or legen produced by Village-Owned Enterprises.

The following are the fields of business that have been running in the village of Hendrosari:

Table 1.SomeIndustries Village

\begin{tabular}{|c|c|c|}
\hline \multicolumn{2}{|c|}{ IndustrialName } & \multirow{2}{*}{$\begin{array}{l}\text { Production result } \\
\text { Grilled chicken }\end{array}$} \\
\hline 1. & $\begin{array}{l}\text { RM Lesehan Berkah } \\
\text { Ilaahi }\end{array}$ & \\
\hline 2. & $\begin{array}{l}\text { Rumah Makan Pak } \\
\text { Wito }\end{array}$ & Grilled chicken \\
\hline 3. & $\begin{array}{l}\text { Depot Ayam } \\
\text { Panggang Ibu Hj. } \\
\text { Suminah }\end{array}$ & Grilled chicken \\
\hline 4. & $\begin{array}{l}\text { RM Dua Siwalan } \\
\text { Cak Pa'i }\end{array}$ & Grilled chicken \\
\hline 5. & Warung RD & Fried Eel, Fried Catfish \\
\hline 6. & $\begin{array}{l}\text { Pecel Belut Pak } \\
\text { Hari }\end{array}$ & Fried Eel, Fried Catfish \\
\hline 7. & \begin{tabular}{lr}
\multicolumn{2}{l}{ Warung } \\
Cak Dul \\
dan & $\mathrm{Bu}$ \\
Tutut &
\end{tabular} & Fried Eel, Fried Catfish \\
\hline 8. & $\begin{array}{l}\text { Legen Asli } \\
\text { Cak Lim }\end{array}$ & Legen \\
\hline 9. & $\begin{array}{l}\text { LLegen } \\
\text { Asli Pak }\end{array}$ & Legen \\
\hline & $\begin{array}{l}\text { Legen Asli } \\
\text { Pak Juli }\end{array}$ & Legen \\
\hline 11. & $\begin{array}{l}\text { Rumah } \\
\text { Makan Sari } \\
\text { Legen }\end{array}$ & Legen \\
\hline 12. & $\begin{array}{l}\text { Legen } \\
\text { Siwalan H. } \\
\text { Ponnadhir }\end{array}$ & Legen \\
\hline
\end{tabular}



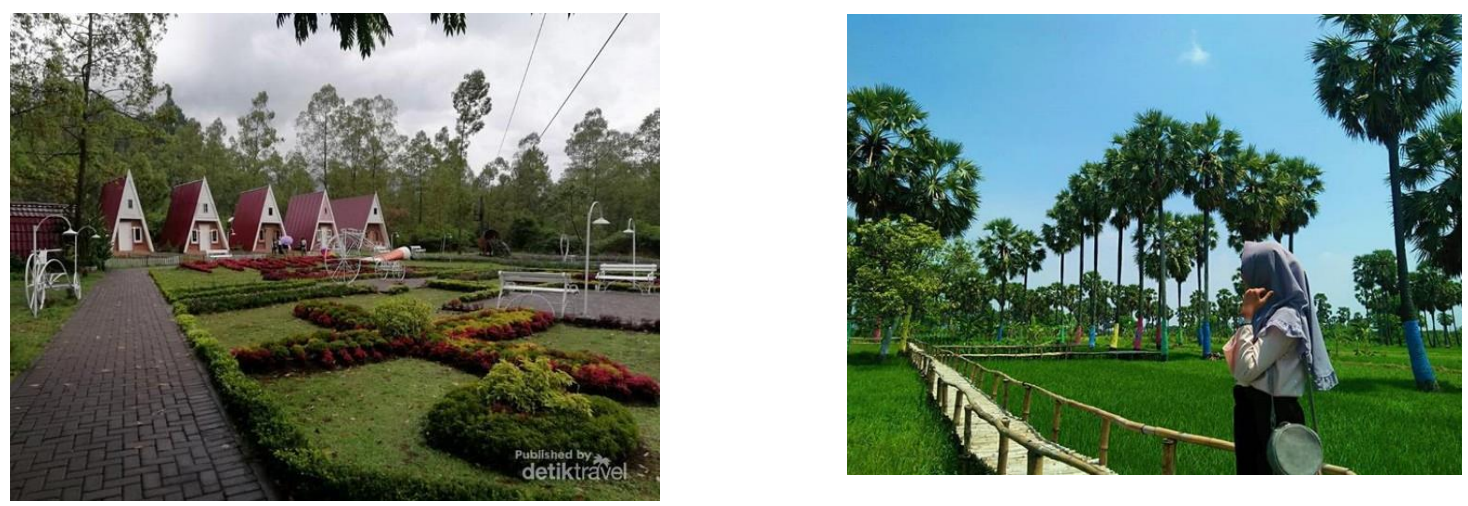

Figure 1. Potential Conditions in Hendrosari Village for Tourism

The opportunityto develop Hendro sari village, especially in the tourism sector with an area of about 10 hectares by making rides for selfie areas and playgrounds for children. In addition, the creation of a system for the implementation of the village tourism program and management improvement in its management needs to be carried out for the implementation of Lontar Sewu educational tour activities.

This is a step to increase the economic level of the Hendrosari village community and the income of the Hendrosari village. Thus this will provide optimal results both for villagers and the village government itself.

As a result, there has been an increase in community income with the realization of Education and strengthening knowledge about business and management. The number of visitors reached 3,000 visitors with revenues from parking around Rp.7 million to Rp.10 million. Not only that, the community can sell their local products to visitors who attend. Culinary entrepreneurs who have long run their businesses also enjoy increasing income because of the large number of visitors at the Lontar Sewu site.

Therefore, it is necessary to design a tool with the application of ergonomics because ergonomics is a science that examines limitations, strengths, and human characteristics by utilizing information to design products, machines, facilities, environment, and even work systems in order to achieve the best quality work without ignoring health, safety, and human comfort aspects of its users (Sumardi, 2015).

The benefits ofimplementing ergonomics are reducing work accidents and work-related morbidity, reducing medical costs,compensation and stress, improving productivity and work flow andcreating asense of security because they are free from injury and increased job satisfaction (Sulaiman and Sari,2018).
From the description of the condition of Hendrosari Village, it is concluded that there is potential for land that can be developed for tourism. But there needs to be an increase in management knowledge and management skills so that education can run well and optimally (Sulistiyani dan Rosidah, 2009 : 220).

\section{Method}

Method and approaches in the PKM program we offer solutions through seminars and workshops to the community about the potential of rural tourism and explore its potential with the economic activities of rural communities.

\section{Results and Discussion}

From the activities carried out during the PKM process, we provide output targets and solutions in the hope of bringing good and productive results to the economy. And able to discuss economic opportunities from villages in the village of Hendrosari. can also be changed from traditional to modern.

\section{- PKM Program Activities}

\section{Location of ActivitiesorPartner Activities}

Theactivitiesoractivitiesofpartnerss ofarhave beencarried out inHendrosari village Menganti area of Gresik City. 


\section{Seminar and Workshop "Development of Tourism Village Potential}

In conducting seminars and workshops, our PKM team invited the entire community and village apparatus by providing some material on how to explore and develop rural tourism. The enthusiasm and enthusiasm of the participants in the seminar and workshop (community and village officials) made us even more excited. Basically they are aware that their knowledge is very minimal, this is what we then together with the participants explored more precisely to explore what the potential is that can be extracted and used as a source of community income? Also explore how much the potential of this village can be developed into a tourist village? What should be done? We discussed all of this and we noted it with a note of recommendations from our PKM team.

First, it provides insight and moves the village community to optimize the potential of the village starting from the economic, social, natural and educational potential (eduwsiata), culinary centers (culinary tourism) and agro-tourism-based entertainment.

Second, provide enlightenment and ensure that the village of Hendrosari is a village that has the potential to become a large tourist village in the future. Therefore, our team continued the discussion by reviewing the history and origins of siwalan fruit and trees, which in the end got a finding, namely the potential for the future of the village of Hendrosari to become a tourism village not only lontar siwalan, but also a tourism education center based on local wisdom.

The three suggestions and recommendations from the team were proposed to the village government to be followed up in order to do further coaching and encourage the community to be more aggressive in terms of utilizing the existing potential as a source of income and income, both the village and the community itself.

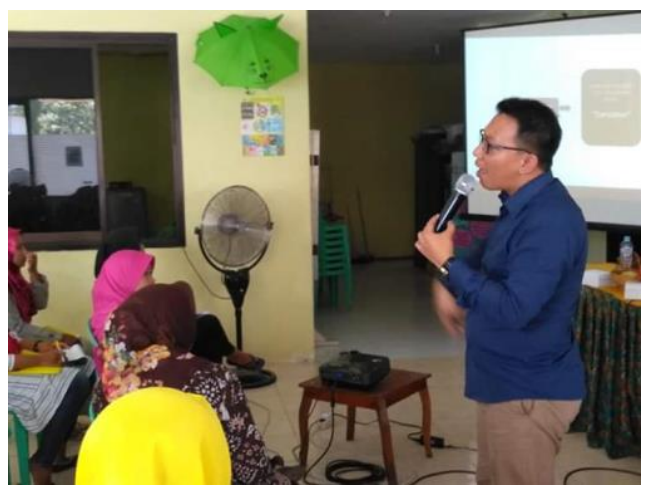

Figure 2. Provide Seminar and Workshop Materials for Tourism Village Development.
3. Site Visit "Discussion of the Future of Hendrosari Tourism Village"

During a visit to our location, the PKM team was shown one by one the village community business units around the village area, culinary eating bekokok chicken and typical Siwalan ice drinks, as well as showing the scenery according to the analysis of our team PKM from the University of Muhammadiyah Gresik campus that the village was worthy developed into an agrotourism-based tourism village, where there are business units related to lontar which can have economic potential, as our team recommends, namely:

1) Utilizing siwalan fruit and siwalan tree in the context of education can be an educational tour, where visitors will be able to get information and knowledge about how the siwalan fruit is from the fruit picking process, until it is processed into a product both legen drinks and other products. This will really give a feel and be a good educational media for the visitor community.

2) $\mathrm{We}$ recommend making tourist attractions by arranging tourist layouts and concepts such as those in Malang and Batu.

3) $\mathrm{We}$ also provide other recommendations, namely culinary. A culinary wista that serves a menu of authentic local food and drinks.

If our recommendation from the PKM team is carried out at least it will add legenbased agro-industry business units, siwalanbased tourism, local wisdom-based culinary and typically legen or siwalan, and will certainly be an additional source of community income and cash for the village. Karnea however if it has become a tourist village, visitors are not only domestic but international (travelers from neighboring countries). 


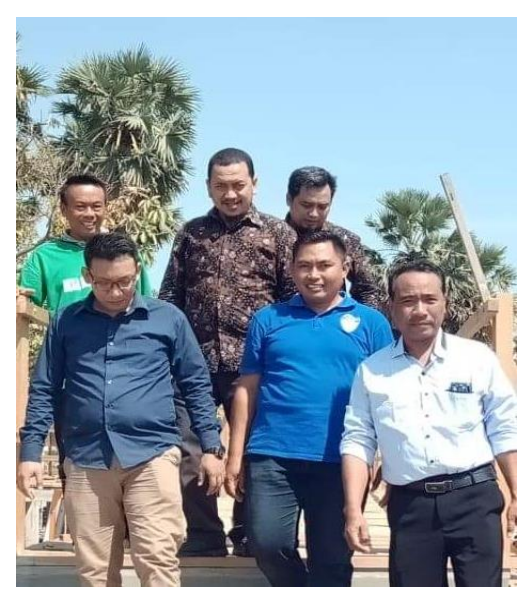

Figure 3. Site Visits that will Potentially be Developed into Tourist Villages.

\section{Conclusion}

conveyare:

Some conclusions that the author can

1. The issue of community knowledge about the potential and how to develop villages into tourism villages by being given a briefing namely seminars and workshops by the PKM Team with the theme "Development of Tourism Villages in Hendrosari Village, Gresik City, in February 2020.

2. The solution offered is the concept of business management and the use of technology in the field of agribusiness and agro-tourism based business management. Discussion solutions were carried out in the potential area of lontar tourism villages, in February 2020.

3. Thepublicationoftheeventwascarriedouton Instagram and Facebook as one of the outcomes that the PKM GrantTeamhad promised whensubmittingthe proposal.

\section{References}

Kurniawan, A. 2018. Start, Run And Grow BUMDesa. UMG Press, Gresik

Profil Desa Hendrosari. Available from: https://hendrosaridesaid.wordpress.com/poten si-desa/Diakses 22 Februari 2020

Sumardi, A. 2015. Perbaikan Sistem Kerja Dengan Pendekatan Ergonomi Total Guna Peningkatan Kenyamanan Pekerja (Studi Kasus di UKM Genteng Press SK2, GodeanKM11,Sleman).Tesis,UPN"Veteran" Yogyakarta.

Sulaiman,F., Sari,Y. P. 2018. Analisis Postur Kerja Pekerja Proses Pengesahan Batu Akik dengan Menggunakan Metode Reba. Jurnal Teknovasi:Jurnal Teknik dan Inovasi,3 (1),1625 . 